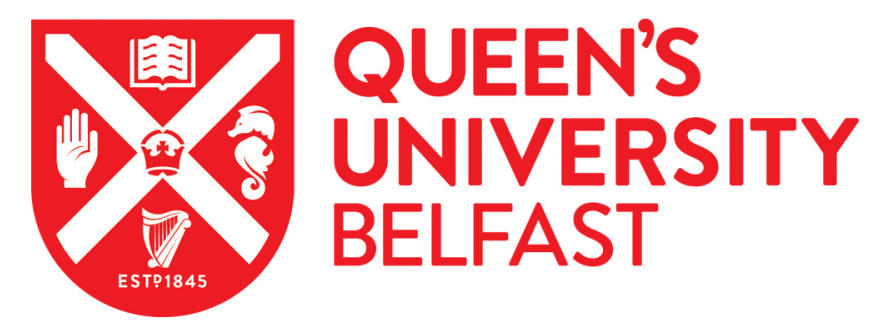

\title{
Barriers, Costs, and Attitudes Toward Pediatric Cataract Surgery at Two Large Facilities in China and India
}

Wang, J., Jin, L., Lu, Q., Borah, R. R., Ali, R., Li, J., Chakraborti, C., Kumar, M., Pan, J., Gilbert, C., \& Congdon, N. (2018). Barriers, Costs, and Attitudes Toward Pediatric Cataract Surgery at Two Large Facilities in China and India. Ophthalmic Epidemiology, 1-8. https://doi.org/10.1080/09286586.2018.1513043

Published in:

Ophthalmic Epidemiology

Document Version:

Peer reviewed version

Queen's University Belfast - Research Portal:

Link to publication record in Queen's University Belfast Research Portal

Publisher rights

Copyright 2018 Taylor and Francis. This work is made available online in accordance with the publisher's policies. Please refer to any applicable terms of use of the publisher.

\section{General rights}

Copyright for the publications made accessible via the Queen's University Belfast Research Portal is retained by the author(s) and / or other copyright owners and it is a condition of accessing these publications that users recognise and abide by the legal requirements associated with these rights.

Take down policy

The Research Portal is Queen's institutional repository that provides access to Queen's research output. Every effort has been made to ensure that content in the Research Portal does not infringe any person's rights, or applicable UK laws. If you discover content in the Research Portal that you believe breaches copyright or violates any law, please contact openaccess@qub.ac.uk. 
Barriers, Costs and Attitudes towards Pediatric Cataract Surgery at Two Large Facilities in China and India

Jun Wang ${ }^{1}$, Ling Jin ${ }^{1}$, Qing Lu ${ }^{2}$, Rishi Raj Borah ${ }^{2}$, Rahul Ali ${ }^{2}$, Junhong $\mathrm{Li}^{4}$, Chandni Chakraborti ${ }^{3}$, Manish Kumar ${ }^{3}$, Jessica Pan $^{5}$, Clare Gilbert ${ }^{6}$ and Nathan Congdon ${ }^{1,2,7}$

1. State Key Laboratory of Ophthalmology and Division of Preventive Ophthalmology, Zhongshan Ophthalmic Center, Sun Yat-sen University, Guangzhou, Guangdong, China.

2. Orbis International, New York, NY, United States.

3. Vivekananda Mission Asram Netra Niramay Niketan, Purba Medinipur, West Bengal, India

4. Shanxi Eye Hospital, Taiyuan, Shanxi, China.

5. Department of Epidemiology, Mailman School of Public Health, Columbia University, New York, NY, United States.

6. International Centre for Eye Health (ICEH), Clinical Research Department, London School of Hygiene \& Tropical Medicine, Keppel Street, London, WC1E 7HT, UK.

7. Translational Research for Equitable Eyecare, Center for Public Health, Queen's University Belfast, Royal Victoria Hospital, Belfast N. Ireland BT12 6BA

Correspondence: Nathan Congdon, State Key Laboratory of Ophthalmology and Division of Preventive Ophthalmology, Zhongshan Ophthalmic Center, Sun Yat-sen University, Guangzhou, People's Republic of China 510060; and Translational Research for Equitable Eye care, Center for Public Health, Queen's University Belfast, Royal Victoria Hospital, Institute for Clinical Sciences Block B, 274 Grosvenor Rd, Belfast N. Ireland BT12 6BA; ncongdon1@gmail.com.

Commercial Interest: The authors have no financial relationships with any organisations that might have an interest in the submitted work in the previous three years; and no other relationships or activities that could appear to have influenced the submitted work.

Key Words: Barrier, cataract, children, socioeconomic status, China, India 


\section{Abstract}

Purpose: To better understand barriers to, costs of and attitudes toward pediatric cataract surgery in China and India.

Methods: From January 2014 to June 2015, families of children $<=10$ years old about to undergo or having completed surgery for bilateral, non-traumatic cataract at 2 tertiary centers in China and India completed questionnaires regarding their demographic characteristics, financial status, living environment, health seeking behaviors and medical burden.

Results: In China, 38 children (23 boys [60.5\%], mean age 3.11+/- 2.88 years) were un-operated, and 44 (26 boys [59.1\%], mean age $5.09+/-2.17$ years) had undergone surgery, while in India there were 60 (44 boys [73.3\%], mean age 4.61 +/- 3.32 years) and 39 (29 boys [74.4\%], mean age $6.45+/-2.74$ years) children respectively, 181 in total. Chinese children were younger at presentation $(\mathrm{P}<=0.03$ for both operated and un-operated) and also when cataract was detected (median [inter quartile range] 10 [3-34] vs. 24 [6-60] months $[\mathrm{P}=0.06]$ for un-operated, 5 [2-12] vs. 36 [8-72] months [P<0.001] for operated). Maternal education levels were lower in India (48.3\% and 51.3\% with elementary education only among un-operated [P=0.11] and operated $[\mathrm{P}=0.006]$ families in India vs. $27.0 \%$ and $20.5 \%$ in China), as were rates of consulting medical practitioners for illness (44.7\% and 36.4\% for un-operated $[\mathrm{P}<0.001]$ and operated $[\mathrm{P}=0.001]$ in China vs. $10 \%$ and $5.13 \%$ in India).

Conclusions: Socioeconomic challenges to securing cataract surgery may be greater, and delays in obtaining surgery longer, in India compared to China, if these facilities are representative. 


\section{Introduction}

Among 1.4 million children who are blind worldwide, cataract is responsible for $10.7-14 \%,{ }^{1}$ making it the leading cause of surgically-treatable blindness in children in many resource-limited countries. ${ }^{2,3}$ The only effective treatment for visuallysignificant pediatric cataract at present is surgery. Advances in instrumentation and technique have led to a significant decrease in complication rates, improving the potential for good visual outcomes. ${ }^{4,5}$ Unfortunately, in low income countries, delayed time to detection, lag between diagnosis and surgery and limitations in operative technique may result in poor outcomes in many cases, ${ }^{6}$ with a significant number of children remaining blind due to deprivation amblyopia, surgical complications and limited opportunities for rehabilitation, including access to timely and accurate refraction. ${ }^{7}$ However, meticulous surgery can lead to fewer post-operative complications. ${ }^{8}$

Although there is a considerable body of evidence on why adults with cataract do not access surgery, there are fewer studies on children, which requires community-based studies of children with unoperated cataract. A study in Malawi showed that not accessing services was associated with low socioeconomic status and low education of mothers, with low levels of awareness of cataract and its causes and treatment. ${ }^{9}$ The main reasons reported by parents were fatalistic views or that treatment was not needed, fear of surgery, long distances to and from the hospital and a preference for traditional remedies. . A similar study in Tanzania revealed barriers at the level of the individual, family, community, and institution. ${ }^{10}$ However, we are not aware of any studies from Asia, although there is some evidence that girls with bilateral cataract are less likely to access surgery than boys in Asian countries. ${ }^{11}$

The cost of childhood cataract is far greater than for adult surgery, as specialized surgical centers may lie at a great distance; family members need to travel with the child; inpatient stays are longer; hospital charges are higher due to more prolonged surgery and the need for general anesthesia; regular follow up is essential for optimal visual outcomes; and children may need to change spectacles frequently as the eyes develop. ${ }^{12,13}$ Although there are studies showing cost as one of the barriers to uptake of cataract surgery in China and India ${ }^{14,15}$, few have investigated the economic impact of cataract surgery on children and families. We carried out a pilot questionnaire survey in Shanxi Eye Hospital, China and Vivekananda Mission Asram Netra Niramay Niketan, India, to explore the barriers and costs associated with the detection and management of pediatric cataract in India and China. The study was designed to provide information for a future trial of financing interventions to promote early uptake of surgery and adherence with post-operative care among families with affected children in these settings. 


\section{Material and methods}

The protocol was approved in full by the Ethics Committee at Zhongshan Ophthalmic Center, Sun Yat-sen University (Guangzhou, China) and Vivekananda Mission Asram Netra Niramay Niketan (Purba Medinipur, India). Written informed consent was given by at least one parent of all children, and the principles of the Declaration of Helsinki were followed throughout.

\section{Study Setting and Subjects}

The study was conducted in the Shanxi Provincial Eye Hospital, Taiyuan, China and Vivekananda Mission Asram Netra Niramay Niketan (VMA NNN), Purba Medinipur, India. Shanxi province (population 36,728,000) ranks 27 th out of 31 administrative units in China, ${ }^{16}$ with a per capita GDP of US\$5349 in 2013, while Purba Medinipur (population 5,095,875 in 2013 ) is identified as one of the 250 "most backwards districts" of India, and has a per capita gross domestic product (GDP) of US\$1338 (2013-14). ${ }^{17}$ The government-run Shanxi Provincial Eye Hospital is the only tertiary eyecare center in Shanxi Province, and performs the bulk of pediatric cataract surgery for the province. VMA NNN is a 100-bed, privately-own, not-forprofit eye hospital, consisting of 40 free beds and 60 paying beds, providing eye care services to a poor, rural population of approximately 10 million in West Bengal, India. The facilities were selected as having pediatric cataract service provision models representative of their respective countries.

From January 2014 to June 2015, we enrolled consecutive families of children $\leq 10$ years old presenting with bilateral congenital or developmental cataract at the outpatient departments of these facilities. Un-operated children were those having visually-significant lens opacities in the opinion of examining ophthalmologists at both hospitals, and operated children had received bilateral surgery for congenital or developmental cataract, confirmed by examination of medical records. We focused our assessment on the behavior and motivations of families having received cataract services for both of a child's eyes, as those operated in only one eye may represent an intermediate group, for whom barriers to care have not been completely removed. Exclusion criteria included traumatic cataract and bilateral cataract with only one eye operated, as trauma and previous surgery may have influenced parents' health seeking behavior.

\section{Questionnaires}

The present study used 5 sub-questionnaires (1) demographic characteristics and financial status, (2) living environment, (3) family quality of life, (4) health seeking behaviors, and (5) direct and indirect medical costs including for transport, food, lodging and economic losses due to absence from work. Costs related to transportation, accommodation and medical service were calculated based on receipts provided by patients for tickets, lodging fee invoices and bills for hospital services. Salary loss was calculated based on subjects' reporting monthly salary. The questionnaire on family quality of life was developed by the Beach Center on Disability, at the University of Kansas. ${ }^{18}$ Interviewers were trained face-to-face by the study team, reviewing each item in the questionnaire with patients and families to clarify any misunderstandings. Investigators interviewed each enrolled family alone, with all families completing the first three questionnaires, families of un-operated children answering the questionnaire on health seeking behaviors, and families of operated children administered the questionnaire on medical costs and burden after completing surgery in both eyes. 


\section{Statistical Methods}

Data are presented as mean (standardized deviation, SD) or median (inter quartile range, IQR) for continuous variables and frequency (percentage) for categorical variables. Family wealth was estimated by summing the value, as reported in the China Rural Household Survey Yearbook (Department of Rural Surveys, National Bureau of Statistics of China, 2013), of household items owned by the family from a previously-defined list of 13 common objects. Differences in demographic, financial and clinical information between operated and un-operated children, and differences between Chinese and India children, were analyzed by two-sample $\mathrm{t}$ test or Wilcoxon rank-sum test for continuous variables, and Chi-square test or Fisher exact test for categorical variables. Wilcoxon rank-sum test was also used to compare findings in China and India in relation to healthseeking behaviors and potential barriers to care with 5-point Likert scale among un-operated children, and the cost before, during and after surgery among operated children. The items related to spectacle acceptance post-operatively among operated children were compared between China and India with Chi-square test or Fisher exact test, and Wilcoxon rank-sum test for cost to buy glasses. All cost data were converted to purchasing power parity, which is measured in terms of national currency per US dollar. ${ }^{19}$ Statistical analysis was done using a commercially available software package (Stata 12.0, StataCorp, College Station TX, USA).

\section{Results}

A total of 181 children presenting with bilateral congenital or developmental cataract participated in this study. In China, 38 (23 boys [60.5\%]; mean age: $3.11 \pm 2.88$ years) children awaited surgical treatment and 44 (26 boys [59.1\%); $5.09 \pm 2.17$ years) had already undergone surgery. In India, the figures were 60 (44 boys [73.3\%]; 4.61 3.32 years) children and 39 (29 boys [74.4\%]; $6.45 \pm 2.74$ years), respectively. In both countries, boys comprised more than half of each group, with India having nearly $75 \%$ male participants (Table 1 ).

Comparing un-operated and operated children in China, there were no differences in parental education level, mother's occupation, number of siblings, and distance to the nearest facility (Table 1). However, economic status was a significant predictor of uptake of pediatric cataract surgery in China: families of operated children were wealthier, possessing a median estimated wealth of US\$2,458 (IQR: \$993-3,238), compared to families of un-operated children US\$1,480 (IQR: \$840-1,905, $P=0.002)$. Similarly, $56.8 \%$ of Chinese families with operated children indicated that they did not encounter issues paying for medical services $(P=0.001)$, while $71.1 \%$ of families with un-operated children relied on borrowing money from within the family or from community members $(P=0.003)$. The proportion of families seeking medical advice from another family member, rather than medical personnel, was greater for un-operated $(5 / 38=13.5 \%)$ than operated children $(0 / 44=0 \%, \mathrm{P}=$ $0.012)$.

Wealth, payment for medical services and having sought medical advice did not differ significantly between families of operated and un-operated children in India. However, Chinese children presented to hospital significantly earlier than Indian children, came from significantly wealthier families who were significantly more likely to describe health expenses as "not a problem." Chinese families were also significantly less likely to rely only on relatives for medical advice, the parents were significantly more likely to have $\geq 12$ years of education, and mothers more likely to work outside the home (Table 1). 
Information on barriers to care and attitudes towards the service was obtained from families of un-operated children (Table 2). In China, lack of awareness of the child's cataracts (78.4\%) was the most commonly reported barrier. Families exhibited confidence in understanding the doctor (70.6\%) and in eventual improvement of their child's vision (80.0\%), and 48.5\% felt able to comply with the provider's recommendations. By comparison, the large majority of Indian families were aware of their children's eye problems $(81.4 \%, \mathrm{P}<0.001)$, and a significantly smaller proportion than in China clearly understood the doctor (39.0\%, $\mathrm{P}<0.001)$, complied with doctor's recommendations $(7.02 \%, \mathrm{P}=0.006)$, and had confidence in their child's recovery $(8.89 \%, \mathrm{P}<0.001)$.

Table 3 summarizes the costs incurred before, during, and after surgery among all operated children. Total cost of surgical treatment was significantly greater for Chinese than Indian families across all three stages of care (all $P<0.001$ ), with a median cost in India of US\$55.5 (IQR: \$27.7-76.7) during surgery, compared to US\$3,800 (IQR: \$2,922-4,755) in China.

The quality of post-surgical care among operated children was assessed by a survey of spectacle acceptance (Table 4), as glasses are commonly needed to correct residual refractive error after surgery. The proportion of families who reported receiving instructions to get glasses (China, $88.4 \%$ and India, $86.8 \%$, $\mathrm{P}=\mathrm{NS}$ ), successfully obtained glasses (China, $90.7 \%$ and India, $81.6 \%, \mathrm{P}=\mathrm{NS}$ ), and ensured that their child regularly wore them (China, $87.2 \%$ and India, $93.3 \%, \mathrm{P}=\mathrm{NS}$ ) were similar in both settings. However, the cost to buy glasses was significantly greater in China (median \$997, IQR: \$513-1,708) than in India (median $\$$, IQR: 0-17.7, $\mathrm{P}<0.001$ ).

\section{Discussion}

Un-operated cataract is a leading cause of blindness in children globally, and can be treated only with surgery. Furthermore, early detection and timely treatment are crucial for maximizing visual acuity and preventing amblyopia, ${ }^{20}$ which poses a challenge to ophthalmologists, patients, and parents ${ }^{21,22}$ For these reasons, it is crucially important to better understand the pathways and barriers to securing timely access to cataract surgical services in low and middle income countries, where the majority of the world's blind children live. ${ }^{23}$ India and China were selected for the current study as the world's two largest countries, with very different approaches to healthcare provision, principally through government facilities in China and largely in the private not-for-profit sector in India.

In our study, family educational levels and health awareness was far lower among patients at the Indian facility than among Chinese patients. Despite the far lower surgical costs for Indian families, and similar mean distance to travel for care, age when the eye problem was noticed and age at presentation were a year or more later at the Indian facility. We hypothesize that the lower rates of maternal work outside the home, tendency to rely only on other family members for medical advice and the greater likelihood of having to borrow money to cover hospital expenses in India may all have been causally associated with delays in access to surgical access among families attending the Indian facility. Likewise, evidence of greater health efficacy among families at the Chinese facility (greater likelihood of understanding the doctor, willingness to ask questions, more confidence in following medical instructions, and in the positive outcome of care) compared to those at the Indian hospital may have functioned causally to bring children into the healthcare system earlier in the Chinese setting. Boys made up the majority 
of children operated in both settings, but this was particularly striking in India, where three-quarters of operated children were male, as has been previously reported. ${ }^{11}$

A number of factors distinguished families of children already operated for cataract in China from those not yet operated, including greater family wealth and greater likelihood that money was "not a problem," lower reliance on family members for medical information and lower rates of current family illness. Taken together, these findings suggest that while access to cataract surgery seems generally to have been smoother at the Chinese compared to the Indian facility, important barriers still existed, and were delaying some families from accessing surgery in timely fashion.

Other studies provide similar reports of delay in presentation for cataract surgery in India and nearby Nepal in children with bilateral cataract. ${ }^{8,24}$ As in the current study, factors associated with late care-seeking behavior in India include lower socioeconomic status, ${ }^{25}$ and lower education levels. ${ }^{9}$ Though evidence regarding cataract service uptake is less prevalent in China, a study from Shandong, Shanxi's neighbor to the east, revealed that nearly half of pediatric patients with bilateral cataract was recognized by 6 months of age. ${ }^{26}$

Strengths of the study include the fact that children and families before and after surgery were assessed in two very different settings using identical protocols and questionnaires; data completeness was good; a broad array of topics relevant to healthseeking behavior were reviewed; and the facilities were large, covering substantial populations. Weaknesses must also be acknowledged: only a single facility in India and China were included, and there were substantial differences between them in crucial areas such as provision of free care, with $40 \%$ of the beds at VMA NNN being reserved for free cases. Thus, institutional differences, including the quality of care provided at each facility, may have had a substantial impact on observed inter-country variations. However, it is also true that government-run, provincial level facilities such as Shanxi Provincial Eye Hospital are typical of those providing pediatric cataract surgical services in China, as is the fee structure reflected in our data, with substantial co-pay fees. Similarly, large private facilities such as VMA NNN with a major service commitment are very common providers of pediatric cataract services in India. Care must be taken in generalizing the findings of our study to other centers in India and China, as the two centers included in this study are recognized centers of excellence which serve specific catchment populations.

Despite these limitations, this study is one of the first to examine factors associated with having received and not yet received cataract surgery in two very different healthcare systems which cover a substantial proportion of the world's children. From a practical standpoint, our study results suggest that health efficacy, education, maternal work outside the home and related factors may play an important causal role in timely uptake of pediatric cataract surgical services, as has been found in other areas of healthcare. ${ }^{27}$ Interventions designed to foster these factors may help to reduce the burden of un-operated cataract on children's vision. 


\section{References}

1. $\quad$ Pascolini D, Mariotti SP. Global estimates of visual impairment: 2010. Br J Ophthalmol. 2012;96(5):614-618.

2. Kong L, Fry M, Al-Samarraie M, Gilbert C, Steinkuller PG. An update on progress and the changing epidemiology of causes of childhood blindness worldwide. J AAPOS. 2012;16(6):501-507.

3. Gilbert CE, Wood M, Waddel K, Foster A. Causes of childhood blindness in east Africa: results in 491 pupils attending 17 schools for the blind in Malawi, Kenya and Uganda. Ophthalmic Epidemiol. 1995;2(2):77-84.

4. $\quad$ Nihalani BR, VanderVeen DK. Technological advances in pediatric cataract surgery. Semin Ophthalmol. 2010;25(56):271-274.

5. Shousha MA, Yoo SH. Cataract surgery after pars plana vitrectomy. Curr Opin Ophthalmol. 2010;21(1):45-49.

6. Mwende J, Bronsard A, Mosha M, Bowman R, Geneau R, Courtright P. Delay in presentation to hospital for surgery for congenital and developmental cataract in Tanzania. Br J Ophthalmol. 2005;89(11):1478-1482.

7. Kishiki E, Shirima S, Lewallen S, Courtright P. Improving postoperative follow-up of children receiving surgery for congenital or developmental cataracts in Africa. J AAPOS. 2009;13(3):280-282.

8. Hennig A, Schroeder B, Gilbert C. Bilateral pediatric cataract surgery: outcomes of 390 children from Nepal and Northern India.J Pediatr Ophthalmol Strabismus. 2013;50(5):312-319.

9. Schulze Schwering M, Finger RP, Barrows J, Nyrenda M, Kalua K. Barriers to uptake of free pediatric cataract surgery in Malawi. Ophthalmic Epidemiol. 2014;21(3):138-143.

10. Bronsard A, Geneau R, Shirima S, Courtright P, Mwende J. Why are children brought late for cataract surgery? Qualitative findings from Tanzania. Ophthalmic Epidemiol. 2008;15(6):383-388.

11. Gilbert CE, Lepvrier-Chomette N. Gender Inequalities in Surgery for Bilateral Cataract among Children in LowIncome Countries: A Systematic Review. Ophthalmology. 2016;123(6):1245-1251.

12. Evans CT, Lenhart PD, Lin D, et al. A cost analysis of pediatric cataract surgery at two child eye health tertiary facilities in Africa. J AAPOS. 2014;18(6):559-562.

13. Gogate P, Dole K, Ranade S, Deshpande M. Cost of pediatric cataract surgery in Maharashtra, India. Int J Ophthalmol. 2010;3(2):182-186.

14. Li Z, Song Z, Wu S, et al. Outcomes and barriers to uptake of cataract surgery in rural northern China: the Heilongjiang Eye Study. Ophthalmic Epidemiol. 2014;21(3):161-168.

15. Marmamula S, Khanna RC, Shekhar K, Rao GN. A population-based cross-sectional study of barriers to uptake of eye care services in South India: the Rapid Assessment of Visual Impairment (RAVI) project. BMJ Open. 2014;4(6):e005125.

16. List of Chinese administrative divisions by GDP per capita. https://en.wikipedia.org/wiki/List of Chinese administrative divisions by GDP per capita\#cite notegdppc1978-2013-8. Accessed March, 7th, 2018.

17. Thukral RK. Purba-Medinipur district factbook. 2017.

18. Balcells-Balcells A, Gine C, Guardia-Olmos J, Summers JA. Family quality of life: adaptation to Spanish population of several family support questionnaires. J Intell Disabil Res. 2011;55:1151-1163.

19. Purchasing power parities (PPP). 2017; https://data.oecd.org/conversion/purchasing-power-parities-ppp.htm. Accessed April 5th, 2018.

20. Lambert SR. Management of monocular congenital cataracts. Eye (Lond). 1999;13 ( Pt 3b):474-479.

21. Hussain AH, Hossain A, Ferdausi N, Islam MZ, Sen U. Visual Outcomes of Congenital Cataract Surgery in a Tertiary Public Hospital in Bangladesh. Asia Pac J Ophthalmol (Phila). 2015;4(5):263-266.

22. Ye HH, Deng DM, Qian YY, Lin Z, Chen WR. Long-term visual outcome of dense bilateral congenital cataract. Chin Med J (Engl). 2007;120(17):1494-1497.

23. Malik ANJ, Mafwiri M, Gilbert C. Integrating primary eye care into global child health policies. Arch Dis Child. 2018;103(2):176-180.

24. Khanna RC, Foster A, Krishnaiah S, Mehta MK, Gogate PM. Visual outcomes of bilateral congenital and developmental cataracts in young children in south India and causes of poor outcome. Indian J Ophthalmol. 2013;61(2):65-70.

25. Senthilkumar D, Balasubramaniam SM, Kumaran SE, Ramani KK. Parents' awareness and perception of children's eye diseases in Chennai, India. Optom Vis Sci. 2013;90(12):1462-1466.

26. You C, Wu X, Zhang Y, Dai Y, Huang Y, Xie L. Visual impairment and delay in presentation for surgery in chinese pediatric patients with cataract. Ophthalmology. 2011;118(1):17-23.

27. Taylor CE, Greenough WB, 3rd. Control of diarrheal diseases. Annu Rev Public Health. 1989;10:221-244. 
Table 1: Demographic, financial and clinical information for operated and un-operated children in India and China

\begin{tabular}{|c|c|c|c|c|c|c|c|c|}
\hline \multirow[b]{2}{*}{ Characteristics } & \multicolumn{4}{|c|}{ Chinese } & \multicolumn{4}{|c|}{ Indian } \\
\hline & $\begin{array}{c}\text { Total } \\
(\mathrm{n}=\mathbf{8 2})\end{array}$ & $\begin{array}{l}\text { Cataract un- } \\
\text { operated } \\
\text { children } \\
(\mathbf{n}=\mathbf{3 8})\end{array}$ & $\begin{array}{l}\text { Cataract } \\
\text { operated } \\
\text { children } \\
(n=44)\end{array}$ & $\begin{array}{c}\text { P-value } \\
\text { comparing } \\
\text { operated } \\
\text { and un- } \\
\text { operated } \\
\text { children }\end{array}$ & $\begin{array}{l}\text { Total } \\
(n=99)\end{array}$ & $\begin{array}{c}\text { Cataract } \\
\text { un-operated } \\
\text { children } \\
(\mathbf{n}=\mathbf{6 0})\end{array}$ & $\begin{array}{l}\text { Cataract } \\
\text { operated } \\
\text { children } \\
(n=39)\end{array}$ & $\begin{array}{r}\text { P-value } \\
\text { comparil } \\
\text { operate } \\
\text { and un- } \\
\text { operate } \\
\text { childre }\end{array}$ \\
\hline Age, years, Mean (SD) & $4.23(2.67)$ & $3.11(2.88)$ & $5.09(2.17)$ & $0.001 \dagger$ & $5.33(3.22)$ & $4.61(3.32)$ & $6.45(2.74)$ & $0.005 \dagger$ \\
\hline Boys, n (\%) & $49(59.8)$ & $23(60.5)$ & $26(59.1)$ & $0.895 \ddagger$ & $73(73.7)$ & $44(73.3)$ & $29(74.4)$ & $0.910 \ddagger$ \\
\hline $\begin{array}{l}\text { One/both parents with } \geq 12 \\
\text { years of education, } \mathrm{n}(\%)\end{array}$ & $22(27.2)$ & $10(27.0)$ & $12(27.3)$ & $0.980 \ddagger$ & $14(14.1)$ & $11(18.3)$ & $3(7.69)$ & $0.237 \ddagger$ \\
\hline $\begin{array}{l}\text { Mother works outside the } \\
\text { home, } n(\%)\end{array}$ & $33(40.7)$ & $16(43.2)$ & $17(38.6)$ & $0.674 t$ & $3(3.03)$ & $3(5.00)$ & $0(0.00)$ & $0.276 \ddagger$ \\
\hline $\begin{array}{l}\text { Estimated family wealth, } \\
\text { US\$, Median (IQR) }\end{array}$ & $\begin{array}{c}3,005(1,555- \\
5,080)\end{array}$ & $\begin{array}{c}2,739(1,555- \\
3,526)\end{array}$ & $\begin{array}{c}4,549(1,838- \\
5,994)\end{array}$ & $0.002 \S$ & $0(0-914)$ & $0(0-731)$ & $0(0-914)$ & $0.623 \S$ \\
\hline $\begin{array}{l}\text { Number of other children in } \\
\text { household, mean (SD) }\end{array}$ & $2.41(0.89)$ & $2.38(1.01)$ & $2.43(0.79)$ & $0.790 \dagger$ & $2.12(1.05)$ & $2.00(0.90)$ & $2.31(1.24)$ & $0.156 \dagger$ \\
\hline $\begin{array}{l}\text { Total number of adults living } \\
\text { in household, mean (SD) }\end{array}$ & $2.78(1.10)$ & $3.14(1.27)$ & $2.48(0.85)$ & $0.007 \dagger$ & $4.01(2.38)$ & $4.05(2.15)$ & $3.95(2.71)$ & $0.837 \dagger$ \\
\hline $\begin{array}{l}\text { Only source of medical } \\
\text { advice for sick family } \\
\text { members is a family } \\
\text { member, } \mathrm{n}(\%)\end{array}$ & $5(6.17)$ & $5(13.5)$ & $0(0.00)$ & $0.012 \ddagger$ & $70(70.7)$ & $46(76.7)$ & $24(61.5)$ & $0.106 \ddagger$ \\
\hline $\begin{array}{l}\text { Distance between household } \\
\text { and nearest hospital, } \\
\text { (kilometer), median(IQR) }\end{array}$ & $9(3-20)$ & $9.5(3-20)$ & $7(2-15)$ & $0.798 \S$ & $10(3-15)$ & $10(3.5-12.5)$ & $6(3-15)$ & $0.556 \S$ \\
\hline \multicolumn{9}{|l|}{$\begin{array}{l}\text { Source of money for medical } \\
\text { service* }\end{array}$} \\
\hline Not a problem & $33(40.2)$ & $8(21.1)$ & $25(56.8)$ & $0.001 \ddagger$ & $5(5.05)$ & $4(6.67)$ & $1(2.56)$ & $0.645 \ddagger$ \\
\hline $\begin{array}{l}\text { Borrowed from family / } \\
\text { community member }\end{array}$ & $44(53.7)$ & $27(71.1)$ & $17(38.6)$ & $0.003 t$ & $76(76.8)$ & $46(76.7)$ & $30(76.9)$ & $0.976 \ddagger$ \\
\hline $\begin{array}{l}\text { Reduced other family } \\
\text { expenses }\end{array}$ & $24(29.3)$ & $9(23.7)$ & $15(34.1)$ & $0.302 \%$ & $1(1.01)$ & $1(1.67)$ & $0(0.00)$ & $0.999 \ddagger$ \\
\hline Other & $17(20.7)$ & $7(18.4)$ & $10(22.7)$ & $0.631 \%$ & $19(19.2)$ & $10(16.7)$ & $9(23.1)$ & $0.429 \ddagger$ \\
\hline $\begin{array}{l}\text { At least one member of } \\
\text { family currently sick } n(\%)\end{array}$ & $27(32.9)$ & $18(47.4)$ & $9(20.5)$ & $0.010 \ddagger$ & $15(15.3)$ & $10(16.7)$ & $5(13.2)$ & $0.638 \ddagger$ \\
\hline $\begin{array}{l}\text { Age of child when eye } \\
\text { problem first noticed, } \\
\text { (months), median (IQR) }\end{array}$ & $5.5(2-24)$ & $10(3-34)$ & $5(2-12)$ & $0.238 \S$ & $28(7-72)$ & $24(6-60)$ & $36(8-72)$ & $0.125 \S$ \\
\hline $\begin{array}{l}\text { Number of times child } \\
\text { received care for cataract, } \\
\text { Median (IQR) }\end{array}$ & $6(3-6)$ & $3(1-3)$ & $6(6-6)$ & $<0.001 \S$ & $3(1-6)$ & $1(1-3)$ & $6(6-6)$ & $<0.001 \S$ \\
\hline
\end{tabular}

Median (IQR)

given in terms of purchasing power parity.

*Binary variables were created for each choice.

$\dagger$ Two-sample t test.

tChi-square test or Fisher's exact test.

§Wilcoxon rank-sum test. 
Table 2: Health-seeking behaviors and potential barriers to care: un-operated children ONLY. (Proportion of families that fully or mostly agreed with each of the statements, on a 5-point Likert scale.)

\begin{tabular}{|c|c|c|c|}
\hline Statement & $\begin{array}{l}\text { China }(\mathrm{N}=38) \\
\text { Cataract un-operated } \\
\text { children, } n(\%)\end{array}$ & $\begin{array}{c}\text { India }(\mathrm{N}=60) \\
\text { Cataract un- } \\
\text { operated children, } n \\
(\%)\end{array}$ & $\begin{array}{c}\text { P-value } \\
\text { comparing } \\
\text { China and } \\
\text { India* } \\
\end{array}$ \\
\hline I was not aware that my child had an eye problem & $29 / 37(78.4)$ & $11 / 59(18.6)$ & $<0.001$ \\
\hline I understood most of what the doctor said to me & $24 / 34(70.6)$ & $23 / 59(39.0)$ & $<0.001$ \\
\hline I asked questions of the doctor & $24 / 33(72.7)$ & $3 / 59(5.08)$ & $<0.001$ \\
\hline I will have no difficulty in following the doctor's recommendation & $16 / 33(48.5)$ & $4 / 57(7.02)$ & 0.006 \\
\hline I am confident that the child's eyes will get better & $28 / 35(80.0)$ & $4 / 45(8.89)$ & $<0.001$ \\
\hline
\end{tabular}


Table 3: Costs of surgery, for operated children ONLY (all figures are in United States dollars (US\$))

\begin{tabular}{|c|c|c|c|c|c|c|c|c|}
\hline \multirow{2}{*}{ Item } & \multicolumn{3}{|c|}{ Before surgery } & \multicolumn{3}{|c|}{ During surgery } & \multicolumn{2}{|c|}{ After surgery } \\
\hline & China & India & P-value* & China & India & P-value* & China & India \\
\hline Transport, median (IQR) & $\begin{array}{c}59.8(18.2- \\
102.5)\end{array}$ & $\begin{array}{l}18.9(11.8- \\
29.5)\end{array}$ & $<0.001$ & $\begin{array}{l}59.8(28.5- \\
113.9)\end{array}$ & $\begin{array}{l}11.8(5.90- \\
21.3)\end{array}$ & $<0.001$ & $\begin{array}{l}56.9(25.6- \\
102.5)\end{array}$ & $\begin{array}{l}17.7(11.8- \\
28.3)\end{array}$ \\
\hline Food, median (IQR) & $\begin{array}{l}14.2(8.54- \\
17.1)\end{array}$ & $\begin{array}{l}5.31(4.13- \\
7.08)\end{array}$ & $<0.001$ & $\begin{array}{c}227.8(153.8- \\
284.7)\end{array}$ & $\begin{array}{c}8.85(3.54- \\
14.2)\end{array}$ & $<0.001$ & $\begin{array}{c}17.1(8.54- \\
19.9)\end{array}$ & $\begin{array}{l}5.31(3.54- \\
7.08)\end{array}$ \\
\hline $\begin{array}{l}\text { Accommodation, } \\
\text { median (IQR) }\end{array}$ & $\begin{array}{l}28.5(17.1- \\
34.2)\end{array}$ & $\begin{array}{c}8.85(4.13- \\
14.2)\end{array}$ & 0.001 & $\begin{array}{l}99.7(28.5- \\
341.7)\end{array}$ & $\begin{array}{l}5.90(2.07- \\
9.44)\end{array}$ & 0.002 & $\begin{array}{l}22.8(17.1- \\
34.2)\end{array}$ & $\begin{array}{l}5.61(0.00- \\
10.6)\end{array}$ \\
\hline $\begin{array}{l}\text { Salary loss for } \\
\text { accompanying family } \\
\text { members, median (IQR) }\end{array}$ & $\begin{array}{l}56.9(28.5- \\
85.4)\end{array}$ & $\begin{array}{l}8.85(0.00- \\
29.5)\end{array}$ & $<0.001$ & $\begin{array}{c}569.5(498.3- \\
854.2)\end{array}$ & $\begin{array}{l}16.5(0.00- \\
35.4)\end{array}$ & $<0.001$ & $\begin{array}{l}99.7(42.7- \\
441.3)\end{array}$ & $\begin{array}{l}8.85(0.00- \\
29.5)\end{array}$ \\
\hline $\begin{array}{l}\text { Hospital cost, median } \\
\text { (IQR) }\end{array}$ & $\begin{array}{l}9.25(6.05- \\
13.6)\end{array}$ & $\begin{array}{l}59.0(5.90- \\
82.6)\end{array}$ & $<0.001$ & $\begin{array}{l}2,681(2,278- \\
3,678)\end{array}$ & $0(0-0)$ & $<0.001$ & $\begin{array}{c}1,160(386- \\
2,000)\end{array}$ & $\begin{array}{l}20.7(14.6- \\
62.0)\end{array}$ \\
\hline $\begin{array}{l}\text { Total cost, median } \\
\text { (IQR) }\end{array}$ & $\begin{array}{c}146(89- \\
225)\end{array}$ & $\begin{array}{l}90.9(51.6- \\
145)\end{array}$ & $<0.022$ & $\begin{array}{c}3,800(2,922- \\
4,755)\end{array}$ & $\begin{array}{l}55.5(27.7- \\
76.7)\end{array}$ & $<0.001$ & $\begin{array}{l}1,290(555- \\
2,782)\end{array}$ & $\begin{array}{l}80.2(48.7- \\
123)\end{array}$ \\
\hline
\end{tabular}

$\mathrm{QR}=$ Inter Quartile Range, USD = United States Dollars, 1USD=3.51 RMB , 1USD=16.9 INR, all values are given in terms of purchasing power parity.

*P-value comparing China and India. Wilcoxon rank-sum test was used for all comparisons. 
Table 4: Spectacle acceptance post-operatively, among operated children ONLY

\begin{tabular}{|c|c|c|c|}
\hline Item & $\begin{array}{c}\text { China }(n=44) \\
\text { Cataract-Operated } \\
\text { children }\end{array}$ & $\begin{array}{c}\text { India }(n=39) \\
\text { Cataract-Operated } \\
\text { children }\end{array}$ & $\begin{array}{l}\text { P-value con } \\
\text { China and }\end{array}$ \\
\hline Parents told to get glasses for their children, $\mathrm{n}(\%)$ & $38 / 43(88.4)$ & $33 / 38(86.8)$ & 0.835 \\
\hline Parents successfully obtained glasses for their children, $\mathrm{n}(\%)$ & $39 / 43(90.7)$ & $31 / 38(81.6)$ & 0.332 \\
\hline Cost to buy glasses, median (IQR), US\$ & $997(513-1,708)$ & $0(0-17.7)$ & $<0.00$ \\
\hline Parents state child regularly wears glasses, $\mathrm{n}(\%)$ & $34 / 39(87.2)$ & $28 / 30(93.3)$ & 0.690 \\
\hline
\end{tabular}

$\mathrm{IQR}=$ Inter Quartile Range, $\mathrm{SD}=$ Standard Deviation, USD = United States Dollars, $1 \mathrm{USD}=3.51 \mathrm{RMB}, 1 \mathrm{USD}=16.9 \mathrm{INR}$, all values are given in terms of purchasing power parity

$\uparrow$ Chi-square test.

tFisher's exact test.

$\S$ Wilcoxon rank-sum test 